7. План дій з реалізації принципів Міжнародної хартії відкритих даних. URL: https://data.gov.ua/pages/plan-dii-z-pryiednannia-odc (дата звернення: 02.09.2021)

8. Про схвалення Концепції розвитку електронної демократії в Україні та плану заходів щодо іiі реалізації: Розпорядження Кабінету Міністрів України від 08.11.2017 № 797-p URL: https://zakon.rada.gov.ua/ go/797-2017-\%D1\%80 (дата звернення: 02.09.2021).

9. Про схвалення Концепції розвитку цифрової економіки та суспільства України на 2018-2020 роки та затвердження плану заходів щодо iii реалізації : Розпорядження Кабінету Міністрів України від 17 січня 2018 року № 67-p., URL: https://zakon.rada.gov.ua/go/ 67-2018-\%D1\%80 (дата звернення: 02.09.2021).

10. Питання Єдиного державного веб-порталу цифрової освіти «Дія. Цифрова освіта» : Постанова Кабінету Міністрів України від 10.03.2021 № 184. URL: https://zakon.rada.gov.ua/go/184-2021-\%D0\%BF (дата звернення: 02.09.2021).

11. Про схвалення Концепції розвитку цифрових компетентностей та затвердження плану заходів 3 іï реалізації : Розпорядження Кабінету Міністрів України від 03.03.2021 № 167-р. URL: https://zakon.rada.gov.ua/go/167-2021-\%D1\%80 (дата звернення: 02.09.2021).

DOI https://doi.org/10.30525/978-9934-26-148-0-30

\title{
ПЕРІОДИЗАЦІЯ ВІТЧИЗНЯНОГО ЗАКОНОДАВСТВА ЩОДО ІНДИВІДУАЛЬНИХ ОБМЕЖУВАЛЬНИХ ЗАХОДІВ В ІНТЕРЕСАХ НАЦІОНАЛЬНОЇ БЕЗПЕКИ: ЗАГАЛЬНА ПОСТАНОВКА ПРОБЛЕМИ
}

\author{
Доронін I. М. \\ доктор юридичних наук, дочент, \\ завідувач наукової лабораторії \\ ДНУ «Інститут інформації, безпеки і права \\ Національної академії правових наук України» \\ м. Київ, Украӥна
}

Надзвичайність та «виключність» (екстраординарність), як постійні ознаки законодавства у сфері національної безпеки, що не оминуло i вітчизняні реалії, зумовили становлення та розвиток так званого «санкційного законодавства». У загальному вигляді слід визначити цей 
термін як сукупність нормативно-правових актів, що встановлюють підстави та порядок застосування тимчасових обмежувальних процедур, які ухвалюються компетентним державним органом в інтересах національної безпеки України на підставі та в порядку, визначеному законодавством, щодо юридичних та фізичних осіб, але ці процедури не носять характеру юридичної відповідальності за вчинення правопорушень [1]. Основними його властивостями, окрім зазначеної вище надзвичайності, вбачаються відсутність характеру юридичної відповідальності, тимчасовість та ухвалення компетентним органом (не завжди судом).

У сучасних умовах законодавство має встановлювати певні вимоги до цих обмежень. Мова йде про: чітке визначення підстав та умов застосування заходів (хоча б і за умови доволі нечіткого характеру самого концепту «національна безпека»); прозора та зрозуміла процедура прийняття рішення з умовою виключення свавільного порядку (процес); наявність гарантій дотримання прав особи при прийнятті рішення та гарантій оскарження прийнятого рішення; тимчасовий характер застосування заходу; наявність вичерпного переліку заходів із зазначенням щодо кожного конкретних обмежень; наявність належного контролю від свавільних дій та розширеного тлумачення на шкоду правам особи.

Оскільки зазначений вид законодавства вже має свою історію і 3 самого початку не був «мертвою нормою», можливо підійти до питання про його періодизацію. Насамперед, слід визначитись із правовими передумовами до виникнення такого виду законодавства.

Ужиття адміністративних механізмів обмежень в міжнародному праві має доволі давню історію. При застосуванні таких санкцій, як правило, мова йшла про специфічні суб'єкти - іноземні держави та їх органи (військо, державний апарат, представники держави). У класичному вигляді мова йшла саме про держави і зумовлювало порядок дій однієї держави проти іншої коли не застосовувались суто воєнні дій (або одночасно з ними). 3 другої половини XX століття зазначені адміністративні заходи окремими державами застосовувались і проти недержавних юридичних осіб (корпорацій) або ж об'єднань осіб з політичною чи релігійною метою. Розповсюдження тероризму, злочинів проти миру та безпеки людства зумовили виникнення «персональних» (індивідуальних) санкцій, що застосовувались міжнародними організаціями. Підставою для їх застосування можливо вважати інтереси міжнародної безпеки та підтримання миру [2]. Імплементація норм міжнародного права у вітчизняному законодавстві та правозастосовчій практиці 
відбувалось в індивідуальному порядку і в межах компетенції державних органів.

Іншою передумовою було застосування обмежувальних заходів в економічній діяльності. Мова йде насамперед про встановлення «спеціальних санкцій» відповідно до ст. 37 Закону України «Про зовнішньоекономічну діяльність» від 16.04.1991. За своїм змістом вони передбачали встановлення штрафів та певного виду обмежень щодо суб'єктів зовнішньоекономічної діяльності, які здійснювали порушення вимог чинного законодавства. Окрім цього, механізм застосування різного виду обмежень у вигляді заборон у господарській діяльності, стягнення штрафів і тому подібні заходи адміністративного впливу передбачались чинним законодавством у випадку правопорушень, що допускались юридичними та фізичними особами.

До числа передумов можливо також віднести і випадки обмежень, що встановлювались при правовій регламентації статусу іноземців та осіб без громадянства у вигляді обмежень на перебування їх на території України.

Зазначені фактори визначають перший етап законодавства, для якого характерно формування відповідного законодавчого масиву, що створило передумови для розробки спеціального законодавчого акту.

Закон України «Про санкції» було ухвалено 14 серпня 2014 року в умовах наявності суспільної дискусії в контексті реагування на прояви агресії проти України. Значний вплив характеру такої дискусії та низка політичних факторів зумовила ухвалення зазначеного законодавчого акту. Ця дата може бути взята до уваги як початок другого періоду розвитку законодавства - ухвалення спеціального законодавчого акту або ж «спеціалізація» законодавства. У подальшому до Закону України «Про санкції» вносились зміни. Зокрема, 09.11.2017 (щодо уточнення повноважень Антимонопольного комітету України), 19.09.2019 (щодо уніфікації термінології із законодавством про публічні закупівлі), 31.03.2020 (щодо встановлення нового виду обмежувальних заходів), 17.07.2020 (щодо уніфікації термінології із законодавством про оборонні закупівлі). При цьому три з чотирьох змін до тексту Закону носять суто технічний характер і полягають в уточненні термінології.

За таких умов постає питання у доцільності виокремлення нового третього етапу в розвитку законодавства. На нашу думку, якщо враховувати лише зміни до спеціального законодавчого акту - Закону України «Про санкції» таке виокремлення є передчасним 3 огляду на те, що грунтовних змін текст Закону не зазнав.

Водночас, варто враховувати і підзаконні нормативно-правові акти та існуючу практику застосування Закону України «Про санкції». За 
таких умов можливе виокремлення етапу розвитку, що може бути охарактеризований як значне розширення сфери застосування приписів Закону у практичній діяльності. Річ у тім, що механізм застосування індивідуальних обмежувальних заходів полягає у прийнятті рішення Радою національної безпеки і оборони України (РНБО), що вводиться в дію Указом Президента України. Від початку застосування приписів Закону України «Про санкції» було намагання до ведення єдиного переліку, який затверджується рішенням РНБО із наступним внесенням до нього змін та доповнень. 3 точки зору юридичної техніки мова йшла про зміни та доповнення до додатку до рішення РНБО, що вводилось в дію Указами Президента України (наприклад, Укази Президента України від 16.09.2015 № 549/2015, від 18.09.2015 № 550/2015, від 27.05.2016 № 225/2016). У подальшому відбулось «оновлення» списку шляхом ухвалення нового рішення РНБО України, введеного в дію Указом Президента України від 15.05.2017 із збереженням загального підходу до формування переліку, викладеного вище. До цих переліків, що були оформлені як додатки, вносились зміни і доповнення у тому числі шляхом виключення окремих позицій. На сьогодні важко стверджувати про причини такого досить складного з точки зору юридичної техніки оформлення рішень про застосування індивідуальних обмежувальних заходів, хоча у деяких випадках це ускладнювало розгляд в судах справ із оскарження Указів Президента України, оскільки оскаржити саме рішення РНБО неможливо.

У подальшому відбулась чергова зміна підходів до застосування положень Закону України «Про санкції». Так, в лютому 2021 року вперше було застосовано секторальні санкції проти окремої держави шляхом ухвалення рішення РНБО від 01.02.2021, введеного в дію Указом Президента України від 01.02.2021 № 41/2021. Підставою для застосування секторальних санкцій були «недружні дії Республіки Нікарагуа, які створюють реальні та потенційні загрози національним інтересам, національній безпеці, суверенітету і територіальній цілісності України, порушують права і свободи людини і громадянина, інтереси суспільства та держави». Рішення було затверджено постановою Верховної Ради України від 02.02.2021 № 1167-IX. Окрім цього, рішення стали значно частішими $\mathrm{i}$ в більшості випадків мова йшла про розширення видів індивідуальних обмежувальних заходів, використовуючи положення п. 25 ч. 1 ст. 4 Закону України «Про санкції»; вперше застосування санкцій проти громадян України, у т.ч. постійно проживаючих на території України (наприклад, Укази від 02.02.2021 № 43/2021, від 19.02.2021 № 64/2021, від 03.03.2021 № 140/2021); застосування індивідуальних обмежувальних заходів без зазначення 
строків застосування («безстроково»), а по суті - відмова від тимчасовості (наприклад, Указ Президента України від 27.02.2021 № 81/2021), а також фактично щотижневі рішення про застосування заходів (особливо, протягом лютого-квітня 2021 року). Зазначені вище фактори дозволяють визначення з 01.02.2021 наступного - третього етапу розвитку законодавства.

Отже, підсумовуюче викладене, варто визнати, що цілком можливо провести періодизацію вітчизняного законодавства щодо індивідуальних обмежувальних заходів, виокремивши принаймні два етапи. Наявність та хронологічні рамки третього є підставою для подальших наукових дискусій.

\title{
Література:
}

1. Доронін I.М. Національна безпека України в інформаційну епоху: теоретико-правове дослідження: автореф. дис. ... докт. юрид. наук. Київ, 2020. С. 26.

2. Birkhauser N. Sanctions of the Security Council against Individuals - Some Human Rights Problems URL: www.esil-sedi.eu/sites/default/files/Birkhauser.PDF (Last accessed: 24.12.2020).

DOI https://doi.org/10.30525/978-9934-26-148-0-31

\section{ОСОБЛИВОСТІ ОФОРМЛЕННЯ КОНТРАКТІВ В КІБЕРСПОРТІ ВІДПОВІДНО ДО УКРАЇНСЬКОГО ЗАКОНОДАВСТВА}

\author{
Косохатько Б. С. \\ магістр Інституту права \\ Київького національного університету імені Тараса Шевченка \\ м. Київ, Україна
}

Щодня перед світовою спільнотою постають нові виклики, які зазвичай потребують сучасного та швидкого рішення. Доволі часто такі рішення є цифровими: починаючи від надання державних послуг і закінчуючи онлайн освітою та медициною.

Цифровізація та інтереси молодого покоління не оминули й сучасний спорт. Вже сьогодні можна побачити, як улюблений футболіст збірної футболу України та професійний кіберспортсмен українського клубу грають в один 3 найвідоміших онлайн шутерів. Такі події не залишаються без уваги широкого кола людей, а тому збирають сотні 